\title{
Yenidoğan Döneminde Konstipasyonunun Nadir Bir Nedeni Laktoz İntoleransı Olabilir
}

\author{
Lactose Intolerance May Be a Rare Cause of Constipation in the Newborn Period
}

\author{
Nevra Koç ${ }^{1}$ Aynur Küçükçongar Yavaş²
}

Geliş tarihi/Received: 18.08.2017 • Kabul tarihi/Accepted: 20.12.2017

\section{ÖZET}

Laktoz intoleransı olan bebek ve çocuklarda büyüme ve gelişmenin devamı ve kemik sağlığının korunmasında diyet yönetimi tedavinin mihenk taşıdır. Yenidoğan döneminde gaz, abdominal distansiyon, sulu dişkılama şikayeti bulunan olgularda laktoz intoleransı düşünülürken, aksine konstipasyonla karşılaşılabileceği de akılda tutulmalıdır. Anne sütü laktaz enzim replasman tedavisi ile birlikte tek başına ilk 6 ay verilmeli, büyüme izlenmeli, zamanında ve diyete özgü tamamlayıcı besinlerle bebek ve çocukların gereksinimleri karşılanmalıdır. Bu yazıda yenidoğan döneminde konstipasyonla laktoz intoleransı tanısı alan ve ağırlık kazanamama şikayeti ile başvuran bir bebek olgu sunulacaktır.

Anahtar kelimeler: Bebek ve çocuk, laktoz intoleransl, diyet yönetimi, laktaz enzim destekleri

\begin{abstract}
Follow up growth and development in infant and children, for protection of bone health is cornerstone of dietary management. Lactose intolerance was considered in the cases of gas, abdominal distention, and water defecation complaints during neonatal period. However lactose intolerance should be kept in mind in cases with constipation. Growth should be monitored and dietary requirements should be met timely initiation of complementary feeding in all children. In this case report, a newborn diagnosed with lactose intolerance with a history of constipation and poor weight gain will be presented.
\end{abstract}

Keywords: Lactose intolerance, infants and children, dietary management, lactase enzyme supplements

\section{Gíriş}

Amerikan Pediatri Akademisi Beslenme Komitesinin laktoz intoleransına ilişkin 1978'de yayınladığı bildiriden sonra geçen 25 yll içerisinde hastalık bilgileri, tanı ve tedavi yaklaşımları ile ilgili önemli gelişmeler olmuştur. Diyetle laktoz alımından sonra ortaya çıkan abdominal ağrı, gaz, distansiyon gibi semptomlar, laktaz enzimi düzeyindeki yetersizliğin derecesine ve diyetle alınan laktoz miktarına bağlı

1. İletişim/Correspondence: Sağlık Bilimleri Üniversitesi Ankara Çocuk Sağllğı ve Hastalıkları Hematoloji Onkoloji Eğitim ve Araştırma Hastanesi, Beslenme ve Metabolizma Bölümü, Ankara, Türkiye • E-posta: nevrakoc@yahoo.com 으 https://orcid.org/0000-0002-4358-4443 olarak diyetteki laktozu sinırlayarak veya laktaz enzim replasmanı kullanılarak tedavi edilebilmektedir (1).

Laktoz, sütün yapısında bulunan bir disakkarit olup glukoz ve galaktoz moleküllerinden oluşmaktadır. Anne sütünün primer karbonhidratı olup özellikle proksimal jejenum galaktosidaz (laktaz) enzimi tarafından hidrolize edilerek kana geçer. Laktoz

2. Sağlık Bilimleri Üniversitesi Ankara Çocuk Sağlığı ve Hastalıkları Hematoloji Onkoloji Eğitim ve Araştırma Hastanesi, Beslenme ve Metabolizma Bölümü, Ankara, Türkiye

(D) https://orcid.org/0000-0002-4766-300X 
intoleransı daha çok bebek ve küçük çocuklarda laktaz enzim eksikliği sonucu laktozun sindirilememesi nedeniyle oluşmaktadır $(2,3)$.

$\mathrm{Bu}$ olgu sunumunda yeni doğan döneminde 15 . günde yoğun gaz ve konstipasyon nedeniyle yapılan tetkiklerinde dış merkezde laktoz intoleransı tanısı alan 5 aylıkken polikliniğimize ağırlık kazanamama ve idrarda kötü koku şikayeti ile başvuran bir olgunun diyet yönetimi sunulacaktır.

\section{OLGU}

Olgu 39. haftada nornal spontan vajinal yol (NSVY), 3450 g olarak dünyaya gelmiştir. İkinci haftanin sonunda, yoğun gaz, abdominal kramp ve konstipasyon (3-4 günde bir dışkılama) şikayeti ile başvurduğu sağlık kuruluşunda laktoz intoleransı tanısı almıştır. Her emzirme öncesi 3 damla laktaz enzim desteği başlanmıştır. Aile öyküsünde inek sütü alerjisi olan ve eliminasyon uygulanan 2 yaşında kardeş mevcuttur. Başvuruda 5 aylık, 6700 g (15. persentil) ağırlığında, $66 \mathrm{~cm}$ (50. persentil) boyunda olan olgu ağırlık kazanamama ve idrarda kötü koku olması nedeniyle hastanemiz metabolizma polikliniğine yönlendirilmiştir. Yapılan tetkiklerinde herhangi metabolik bir hastalığa rastlanmayan olgu, beslenme durumunun değerlendirilmesi ve laktoz intoleransına özgü diyetinin planlanması amacıyla diyet polikliniğine yönlendirilmiştir.

Annenin sütünün sağılması sonucunda günlük verilen süt miktarının 600-700 mL civarında olduğu belirlenmiştir. Olgunun anne sütü ile aldığı günlük enerji miktarı ortalama $656 \mathrm{kkal} / g u ̈ n$, protein miktarı ise $12.35 \mathrm{~g}$ /gün'dür. Bu nedenle anne sütüne ek olarak laktozsuz bebek formülü başlanmıştır. Altıncı ayından itibaren kademeli olarak yoğurt (öncesinde 3 damla laktaz enzimi ile), yumurta sarısı, sebze ve meyve püre, tarhana çorba, sebze çorba gibi yumuşak ayına uygun kıvamlı ek besinlere başlama eğitimi verilerek, emzirmeye devam etmesi önerilmiştir. Olgu ayrıntılı üç günlük besin tüketimi ve gaita izlem kaydı ile aylık olarak kontrollere çağırılmıştır. Tedavi sürecinde hastanın klinik izlemi ve diyet yönetimi Tablo 1'de verilmiştir.

Şu an 12 aylık 11.0 kg (yaşa göre ağırlık 85. persentil, boya göre ağırlık 50. persentil) ve $80 \mathrm{~cm}$ (85. persentil) boy uzunluğuna ulaşan olgunun, günde 1-2 kez ve yumuşak normal kıvamda gaita çıkışı mevcuttur. İlk kontrollerinde gaitada ++++ redüktan madde miktarı son kontrolde +'e ulaşmıştır.

\section{TARTIŞMA}

Laktoz intoleransının tedavisinde temel yaklaşım diyetten laktozun çıkarılması veya azaltılması esasına dayanır (1). Diyetten laktozu yüksek oranda içeren süt ve süt ürünlerinin çıkarılması, laktoz intoleransına bağlı olarak gelişen semptomların ortadan kaldırılmasında önemli bir yer tutmaktadır. Ancak laktoz içermeyen bir diyet örüntüsü ile kalsiyum, riboflavin ve D vitamini yetersizliği ile karşı karşıya kalınmaktadır. Bu nedenle laktoz intoleransı olan bebek ve çocuklarda büyüme ve gelişme için çok önemli olan bu besin ögelerinin gereksinim düzeyinde karşılanması sağlanmalıdır $(4,5)$.

Bebek ve çocuklarda görülen laktoz intoleransı daha çok primer laktaz enzim eksikliğine dayanmaktadır. Bu olguda 15/365 günlükken yoğun gaz ve konstipasyon (3 günde bir rektal irrigasyon ile dışkılama) şikayeti ile başvurduğu sağlık kuruluşunda inek sütü alerjisi ile izlemli kardeş öyküsü nedeniyle de yapılan ileri tetkiklerinde laktoz intoleransı tanısı almıştır.

Anne sütünün laktoz içeriği yüksek ama yağ içeriği düşüktür. Aynı zamanda içermiş olduğu prebiyotik lifler sayesinde fermentasyonla laktozu parçalayıp, laktaz enzimi üreten probiyotik organizmaların gastrointestinal bölgede çoğalmasını da sağlamaktadır. Bu olguda bebeğe her emzirme öncesi laktaz enzimi desteği verilerek 5 aylık oluncaya kadar sadece anne sütü ile beslenmesi sağlanmıştır. Bu sayede günlük kalsiyum alımı gereksinme düzeyinde karşılanmıştır.

Laktoz intoleransı olan olgularda sıklıkla abdominal distansiyonun yanında sulu dışkılama görülmektedir (5). Aksine bu olguda abdominal distansiyon, kramp ve 
Tablo 1. Tedavi sürecinde hastanın klinik izlemi ve diyet yönetimi

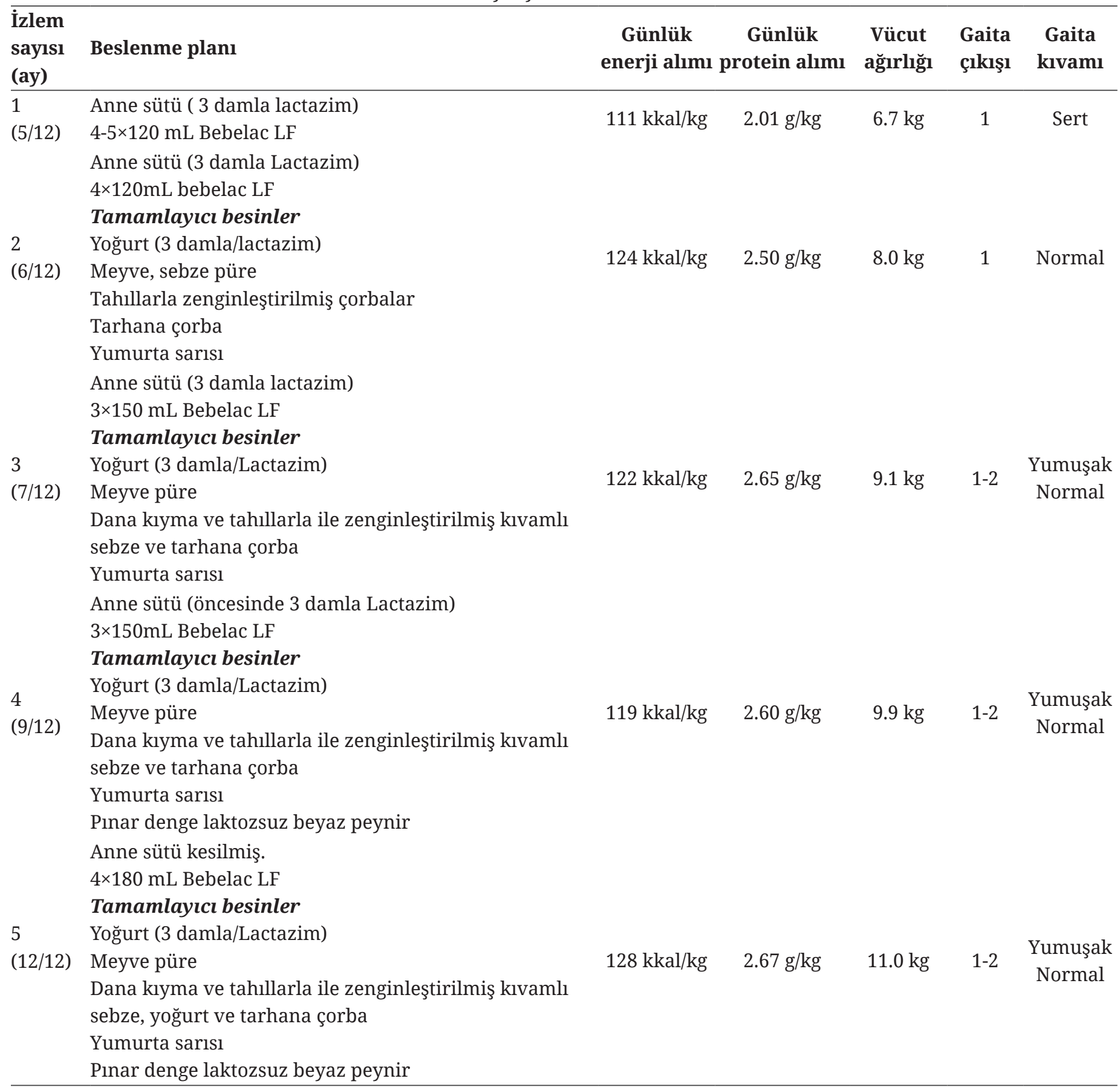

konstipasyon gözlemlenmiştir. Başlanan laktaz enzim desteği ile simbiyotik olan immünglobulinlerden zengin anne sütünün tüketimi laktoz toleransinı arttırarak bebeğin gaz ve kramp şikayetlerini azaltmış yumuşak dişkılama sağlamıştır.

Laktoz intoleransı olan bebek ve çocuklarda akut gastroenterit ve malnütrisyon beklenen bir durumdur. Bu nedenle ağırlık izlemi ve büyümenin izlenmesi büyük önem taşımaktadır $(1,5)$. Olguda sadece anne sütü ile beslenen bebek 5. ayında 6.7 kg (15. persentil) olup ağırlık kazanımı yetersiz bulunmuştur. Poliklinikte beslenme durumu değerlendirilen hastaya ek olarak fermente laktozsuz formül mama 4-5 kez/gün 120 mL olarak başlanmıştır. 
Bir ay sonraki kontrolünde $1.3 \mathrm{~kg}$ tartı artışı olan bebeğe ayına uygun laktozsuz tamamlayıcı besinler başlanmıştır. Az miktarda yoğurdun enzimle beraber denenmesi önerilmiştir. Gaz ve şişkinlik şikayetlerine göre miktarının yavaş yavaş arttırılması konusunda bilgi verilmiştir (Tablo 1).

Laktozun sindirimini diyetin laktoz içeriği (laktoz dozu), kolon adaptasyonu, intestinal geçişi ve tüketilen süt ürünleri önemli ölçüde etkilemektedir (1,4-5). $\mathrm{Bu}$ noktadan hareketle laktoz intoleransinda diyet yönetiminde kullanılacak tedavi modülleri Tablo 2'de verilmiştir. Hastada diyet modifikasyonlarında kontrollerde 9. ayda anne sütü kesilmiştir. Anne sütüne destek amaçlı başlanan laktozsuz formüla miktarı arttırılarak, süt yerine yoğurt kullanarak, laktozu azaltılmış olgun peynir diyete eklenerek kalsiyum gereksinmesi karşılanmaya çalışılmıştır (Tablo 1). Amerikan Pediatri Akademisi (AAP/2006) Beslenme Komitesi laktoz intoleransı olan çocuk ve adolesanlarda diyette laktozun sinırlandırılmasını, daha çok fermente süt ürünlerinin ve laktaz enzim desteklerinin kullanılmasını önermektedir. Ancak komite bu yaş grubunda kemik sağlığı için biyoyararlanımı yüksek ve önemli bir kalsiyum kaynağı olan sütün tolere edilme durumuna göre tek başına $240 \mathrm{~mL} /$ gün (1 su bardağı) veya besinlerle birlikte alınmasının ya da laktozsuz süt ve süt ürünlerinin kullanılmasının önemini de vurgulamaktadır (1).

Laktoz intoleransında diyet yönetiminde laktoz içeren besinlerin diyetten çıkarılıp tolerans düzeyine göre hastaya yavaş yavaş tanıtılması ile klinik semptomlar önemli oranda azalmaktadır. Ancak iyi kalite protein kaynağı olan süt ve süt ürünlerinin diyetten çıkarılması uzun vadede elzem vitamin ve mineral eksikliklerine yol açıp kemik bütünlüğünün bozulmasına yol açabilmekte, bebek ve çocuklarda büyüme gelişmeyi olumsuz yönde etkilemektedir (5). Sonuç olarak yenidoğan döneminde kolik, gaz ve konstipasyonun nedenleri araştırılırken tanı koyarken laktoz intoleransı akılda tutulmalıdır. Bebeklerde laktaz enzim replasmanı ile beraber ilk 6 ay sadece anne sütü verilmelidir. Yoğurt, tarhana gibi fermente süt ürünleri, olgun peynirler, prebiyotik lif eklenmiş pastörize süt ürünleri tedavi planına dahil edilerek bebek ve çocukların enerji, protein, kalsiyum, riboflavin gereksinmeleri daha rahat karşlanabilir ve $\mathrm{D}$ vitamini desteği verilebilir. Beslenme durumu değerlendirilerek büyüme izlenmeli, gerekli diyet düzenlemeleri zamanında yapılmalıdır.

Çıkar çatışması - Conflict of interest: Yazarlar çıkar çatışması olmadığını beyan ederler. - The authors declare that they have no conflict of interest.

Tablo 2. Laktoz intoleransında diyet yönetiminde tedavi modülleri

\begin{tabular}{ll}
\hline Laktoz sindirimini etkileyen etmenler & Diyet düzenlemeleri \\
\hline Laktoz dozu & Tüketilen laktoz miktarı ile laktoz intoleransı semptomları arasında \\
& doğrudan bir ilişki bulunmaktadır. Tolare edilebilecek laktoz miktarı \\
& $12-25$ g’dir. \\
& Sütü diğer besinlerle birlikte tüketmek laktozun intestinal geçiş hızını \\
İntestinal transit & yavaşlatmaktadır. Böylece laktoz intoleransı semptomları azalmaktadır. \\
& Kolon adaptasyonunun arttırılması için laktoz içeren besinlerin günlük \\
Kolon adaptasyonu & olarak az miktarlarda tüketilmesi gerekmektedir. \\
& Diyetin laktoz içeriği 12 g'ın üzerine çıkıyorsa laktaz destekleri \\
Sindirime yardımcılar & kullanılabilir. Laktozu hidrolize edilmiş sütler de iyi tolere edilmektedir. \\
(Laktoz enzim ilaçları, tozları, damlaları vb.) & Yoğurttaki laktoz süt laktozuna göre daha iyi sindirilebilmektedir. \\
Yoğurt ve diğer fermente süt ürünleri & Yoğurttaki aktif bakteri kültürlerinin B-galaktosidaz enzim aktivitesi Gís \\
& semptomlarını azaltmaktadır \\
& Pastörize süt ürünlerine, laktaz pozitif probiyotik bakteri türleri \\
Probiyotikler & eklendiklerinde laktoz sindirimini arttırmaktadır. \\
\hline
\end{tabular}




\section{KAYNAKLAR}

1. Heyman MB. Lactose intolerance in infants, children, and adolescents. Pediatrics 2006;118:1279-1286.

2. Lule VK, Garg S, Tomar SK, Khedkar CD, Nalage DN. Food intolerance: Lactose intolerance. Encyclopedia Food Health 2016.p.43-48.

3. El Sahfie AM, Shaheen HM, El bary Ebrahim ESA. Lactose intolerance among pediatrics: systematic review. Menoufia Med J 2015;28:315-318.

4. Rienzo TD, D’Angelo G, D'Aversa F, Campanale MC, Cesarıo V, Montalto $\mathrm{M}$, et al. Lactose intolerance: from diagnosis to correct management. Eur Rev Med Pharmacol Sci 2013;17:18-25.

5. Samur G. Laktoz intoleransları ve beslenme tedavisi. (Eds: Gokmen Ozel H). Çocuk Sağlığı ve Hastalıklarında Beslenme. TDD Eğitimleri Yayını, Ankara, 2018, s.172

6. Flynn A. The role of dietary calcium on bone health. Proc Nutr Soc 2003;62:851-858. 